\title{
Antecedent and Outcomes of Satisfaction with Service Recovery: A Study among Mobile Phone Users in Central Region of Malaysia
}

\author{
Niriender Kumar Piaralal ${ }^{1}$, Shishi Kumar Piaralal ${ }^{2} \&$ Muhammad Awais Bhatti ${ }^{1}$ \\ ${ }^{1}$ College of Business, School of Business Management, University Utara Malaysia, Sintok-Kedah, Malaysia \\ ${ }^{2}$ Faculty of Business Management, Open University Malaysia, Malaysia \\ Correspondence: Muhammad Awais Bhatti, College of Business, School of Business Management, University \\ Utara Malaysia, Sintok-Kedah, Malaysia. Tel: 60-17-684-8397. E-mail: awaisbhatti_786@yahoo.com
}

Received: March 18, 2014 Accepted: April 29, 2014 Online Published: May 26, 2014

doi:10.5539/ass.v10n12p210

URL: http://dx.doi.org/10.5539/ass.v10n12p210

\begin{abstract}
Purpose: In a competitive service industry, satisfying customer is paramount for sustainability of the organization. With this understanding this current study is investigating on antecedent and outcomes of satisfaction with service recovery in the mobile phone industry with introduction of Mobile Number Portability (MNP) in Malaysia recently.

Design/Methodology: Antecedent of satisfaction with service recovery is perception of justice which consists of interactional, procedural and distributive justice. Outcomes of satisfaction with recovery are behavioral outcomes which are consisting of word of mouth (WOM), customer loyalty and trust. In addition this study also added moderator (service failure severity) to understand the relationship between perception of justice and satisfaction with service recovery. Data gathered by self-administered questionnaires from 280 mobile phone users in central region of Peninsular Malaysia by using convenience sampling technique. Data was analyzed using multiple and hierarchical regression.
\end{abstract}

Findings: The findings indicate perception of justice is an antecedent to satisfaction with service recovery. Service failure severity was found to have moderating effect between perception of justice and satisfaction with recovery. Findings also indicate outcomes of satisfaction with service recovery are behavioral outcomes which consist of word of mouth, customer loyalty and trust.

Limitations: The limitations of this studied noted and further research suggestions are also included that are very important for service recovery.

Values: This research had enhanced and widens the understanding on the effect of service failure severity and effect of service recovery on customer satisfaction for mobile industry in Malaysia.

Keywords: service recovery, customer satisfaction, Malaysian mobile industry

\section{Introduction}

Service is generally regarded as a unique entity from a marketing perspective because it is intangible, non-separable, heterogeneous and perishable in nature and therefore the customer must be present for a service to take effect and it is called service encounter (Zeithaml, Parasuraman, \& Berry, 1985). When a mistake occurs, it is referred to as a service failure and customers' confidence in the company becomes uncertain (Maxham, 2001). The actions of a service provider such as service recovery after the service failure can make things better or worse for the customers (Bitner, Blooms, \& Tetreault, 1990). Most dissatisfied customers who complain will do business again if their problems are solved satisfactorily (Berry \& Parasuraman, 1991). In fact, it has been suggested that, through a phenomenon called the "service recovery paradox" (Michel, 2001), a successful service recovery can result in higher customer satisfaction and loyalty than if no service failure had occurred (Hocutt, Bowers, \& Donavan, 2006). Consequently customer satisfaction with service recovery will be reflected in the bottom line (Stauss \& Schoeler, 2004).

In Malaysia, awareness of customer rights has increased significantly. Customers are not only raising their complaints but also taking a step forward by opting to highlight it to a higher authority or third party if service failures are not addressed properly. The Malaysian Communication Multimedia Commission (MCMC) had 
recorded a 233 percent increase in the number of complaints from 2007 to 2008 (MCMC, 2009). In the telecommunication industry in Malaysia, competition among service providers is fierce and service providers are constantly striving to keep customers satisfied (Business Monitor International, 2009). This is by building and maintaining high quality customer relationship to ensure continued loyalty (Shapiro \& Nieman-Gonder, 2006).

The Malaysia mobile market is made up of mainly 4 mobile network operators namely CELCOM, MAXIS, DIGI and U-MOBILE and is regulated by MCMC. According to MCMC, penetration of mobile phone usage has grown from 9.8/100 in 1996 to 93.9/100 per population in 2008 (Soo, 2009). Currently the penetration rate of mobile phone usage are 117.6/100 per population in 2011 (Business International Monitor, 2011) This penetration rate is have reach above saturation point where it provides the opportunity for service providers to offer various incentives for customers to switch firms easily if dissatisfied with the current service provider (Maxham \& Netemeyer, 2003). Furthermore Frank and Sullivan (2005) reported in their survey that mobile phone users in Malaysia are only medium scale in terms of customer satisfaction and customer loyalty. Medium scale in this case, indicates mobile phone users who are willing to switch service providers when required. Until recently due to hassles of changing numbers when switching to another network, and notifying contacts, many customers had put it off unless it was the last resort (Seth, Momaya, \& Gupta, 2005).

This had worked to the advantage for the service provider. With the introduction of Mobile Number Portability (MNP) in October 2008 (Business Monitor International, 2009), network service providers face new challenges ahead of tackling dissatisfied customers. Competition will be fiercer with MNP gaining momentum. MNP allows customers to choose or switch service provider at any time while maintaining their number. Hence a customer is allowed to switch easily with minimum cost and impact. According to Yuen (2008), 86,636 mobile phone users had made the switch within one month and industry analysts are expecting 5-10 percent will make the switch within a year. This data indicates that customers will switch their service provider easily if the services are not up to the mark.

In today's increasingly competitive world of business, satisfying or even delighting one's customers has become an essential ingredient for success (Johnston \& Michel, 2008). Companies need to be particularly careful as in most cases service failures cannot be hidden from customers (Maxham, 2001). Negative publicity will be generated through the various interactive communications channels and will cause spread of negative word of mouth (Crie, 2003). Loyal customers expect problems to be handle with effectively and are disappointed when they are not, making service recovery key (Zeithaml, Berry, \& Parasuraman, 1993).This can be prevented by emphasizing satisfaction with service recovery as one of service providers business strategies to retain a valuable customer during service failure (Swanson \& Kelly, 2001).

Therefore this studied carried out to understand mobile phone users' effect of service recovery on customer satisfaction especially with MNP introduction and furthermore very little attention has been given in this area by researcher. The objectives of this study are to understand the antecedent and outcomes of satisfaction with service recovery. This study looks at the perception of justice as an antecedent to satisfaction with recovery and service failure severity as a moderator on the relationship between perception of justice and satisfaction with service recovery. Outcomes of satisfaction with recovery are behavioral outcomes which consist of trust, word of mouth and customer loyalty. There were limited research on service recovery related to telecommunications industry in Malaysia and with correct and proper service recovery strategies the service network providers will be able to use this as one of their competitive advantage against their competitors to retain valuable customer.

\section{Literature Review}

\subsection{Satisfaction with Service Recovery}

Service recovery is optimal for airline and banking industry when an employee in the organization has been empowered and is willing to accept blame compared to no empowerment and employee is blames the customer for the service failure (Boshoff \& Leong, 1998). In Tax, Brown and Chandrashekaran (1998) research indicates that for firm that provide poor recovery effort of service recovery strategies through elements of justice may severely limit the customer satisfaction with regard to service recovery encounter. Andreassen (2000) also found that perception of justice for service recovery strategies have an impact on satisfaction with service recovery encounter. In contrasts Sparks and McColl-Kennedy (2001) indicated that service recovery strategies through elements of justice did not impact customer satisfaction with recovery based on 420 respondents in United States hotel industry. 


\subsection{Perceived Justice}

The perception of justice concept is divided in two broad dimensions which are outcomes and processes (Cengiz, Er, \& Kurtaran, 2007). The outcomes dimension is described as distributive justice and refers to evaluation of the perceived outcomes by the customers (Mattila, 2001). Outcomes includes such as compensation, refund, discount or free gift from service providers with aim to turn dissatisfied mobile phone users to satisfy through service recovery effort. For example Sparks and McColl-Kennedy (2001) found that respondents were satisfied when a 50 percent refund was given to compensate for the service failure in the study conducted for restaurant industry in USA. In same manner Yi, Cheng and Wei (2010) found additional compensation will help higher customer satisfaction in Taiwan retailing industry. In a service recovery effort, tangible compensation such as compensation, discount or refund will lead to higher perceptions of distributive justice from mobile phone users' point of view, which in turn will lead to higher consumer satisfaction toward service recovery.

The processes dimension is consist of procedural and interactional justice. Procedural justice refers to processes, rules and policies used by the service providers to rectify the service failure (Smith, Bolton, \& Wagner, 1999). Service providers' policies such as promptness, flexibility and timely feedback are considered as process of evaluation of procedural justice to turn dissatisfied to satisfied customers (Cengiz et al., 2007). Researchers indicate increased in perception of procedural justice by the service providers toward their customer will increase satisfaction toward recovery (Yi et al., 2010).

Interactional justice is focused on the aspect how the customers had been treated during the process to rectify service failure (Mattila, 2001). Processes of evaluation of interactional justice to satisfied customers include courtesy, explanation, fairness and empathy (Tax et al., 1998). For example Goodwin and Ross (1992) found that one elements of interactional justice which is an apology, seems particularly relevant to satisfaction. While Maxham and Netemeyer (2003) indicate that employee's perceptions of interactional justice will impact their customer-directed extra role behaviors.

Based on previous research on service recovery demonstrated positive perceptions of distributive, procedural, and interactional justice significantly enhances overall customer satisfaction with service recovery (Cacado-Diaz, Mas-Ruiz, \& Kasper, 2007). Hence, it is expected that the three justice dimensions significantly contribute to recovery evaluations and explain a high percentage of variation in overall satisfaction with customer assessment of service recovery efforts (Tax \& Brown, 2000). Therefore the following hypotheses will be tested:

H1: There is a positive relationship between perception of justice and satisfaction with service recovery.

H1a: There is a positive relationship between interactional justice and satisfaction with service recovery.

H1b: There is a positive relationship between procedural justice and satisfaction with service recovery.

H1c: There is a positive relationship between distributive justice and satisfaction with service recovery.

\subsection{Service Failure Severity}

Service failure severity refers to perceived severe failure, magnitude of failure or perceived of harm (McCollough, Berry, \& Yadav, 2000). Customer's perceived intensity of a service problem is called as service failure severity. Service failure severity can vary depending on customer's evaluation of service failure (Kelley \& Davis, 1994). Previous research suggests that the severity of the service failure will be influential in the evaluation of a service provider after a service failure and it is also a challenge for service providers to execute an effective service recovery when the failure is perceived as severe (Mattila, 2001).

According to Weun et al. (2004) service failure severity was hypothesized to moderate the relationship between perception of justice and satisfaction with recovery for mail order and restaurant industry. Their findings indicate that service failure severity had negative relationship with satisfaction with service recovery. Their finding also highlighted that service failure severity had only moderating effect for relationship between distributive justice and satisfaction with recovery.

As the service problem becomes more severe, the potential for customer dissatisfaction will increase too (Weun et al., 2004). An outstanding service recovery with high levels of perception justice may not be sufficient to overcome a severe service failure since customers use a non-linear value function to evaluate service recovery outcomes (Smith et al., 1999). The variation toward the way customers respond to service failure indicates that the service failure severity had an impact to satisfaction with service recovery (Magnini et al., 2007). Therefore when service failure becomes more severe, the positive influence of perception justice on satisfaction with service recovery judgments decreases and the following hypotheses are offered:

H2: The perceived severity of a service failure will moderate the relationship between perception of justice and 
satisfaction.

\subsection{Behavioral Outcomes}

Behavioral outcomes consist of trust, customer loyalty and word of mouth (WOM) (Kau \& Loh, 2006). Findings from research had indicated that satisfaction with recovery will lead to positive behavioral outcomes (Cengiz et al., 2007). One of behavioral outcomes, trust had been found to be the essential component in the development of marketing relationships (Morgan \& Hunt, 1994). Trust is exhibited when "one party has confidence in an exchange partner's reliability and integrity" (Morgan \& Hunt, 1994). Confidence on the part of the trusting party results from the continuing belief that the trustworthy party has integrity, which is associated with such attributes as honesty, justice, responsibility and helpfulness (Oliver, 1980). Crosby et al. (1990) contends that trust is strengthen when partners take action in ways that acknowledge an individual's specific needs and affirm their sense of worth. Trust is an important ingredient in firm customer relationships in Malaysia and elsewhere (Ndubisi, 2005).Trust formation will also be strengthened further with repeated satisfaction over time (Ganesan, 1994). In a similar manner, trust is the outcome from satisfaction with service recovery.

Ndubisi (2004) suggested that loyal customers are valuable communicators of favorable word-of-mouth about organizations or products to which they feel loyal. Reichheld and Sasser (1990) reported that a service company could boost profits by 100 percent just by increasing customer retention rate by 5 percent. Retention is believed to be a function of existing customers' level of satisfaction. Other studies have also shown that an important variable that contributes to customer and employee commitment is satisfaction (Kelley et al., 1993). When a firm develops a good system of resolving customer complaints, it leads to greater customer loyalty (Tax \& Brown, 2000). On the other hand, Tax et al. (1998) discovered that as dissatisfaction with complaint handling increases, commitment would decrease. Similarly, Andreassen (1999) also affirmed that satisfaction with service recovery has a strong impact on customer loyalty. As such, it can be hypothesized that satisfaction with service recovery would lead to higher consumer loyalty. Following hypotheses will be tested based on explanation of how satisfaction with recovery of complainers (mobile phone users who choose to highlight their service failure with service providers, Kau \& Loh, 2006) will affect behavioral outcomes (consisting of customer loyalty, WOM and trust):

H3: There is positive relationship between satisfaction with service recovery and behavioral outcomes.

H3a: There is positive relationship between satisfaction with service recovery (complainers) and trust.

H3b: There is positive relationship between satisfaction with service recovery (complainers) and WOM.

H3c: There is positive relationship between satisfaction with service recovery (complainers) and customer loyalty.

Following hypotheses will be tested based on explanation of how initial satisfaction of non-complainers (mobile phone users who are satisfied with the service provided due to no service failures or choose not to highlight their service failure to the service provider, Kau \& Loh, 2006) will affect behavioral outcomes (consists of customer loyalty, WOM and trust):

H4: There is positive relationship between satisfaction of non-complainers and behavioral outcomes.

H4a: There is positive relationship between satisfaction (non-complainers) and trust.

H4b: There is positive relationship between satisfaction (non-complainers) and WOM.

H4c: There is positive relationship between satisfaction (non-complainers) and customer loyalty.

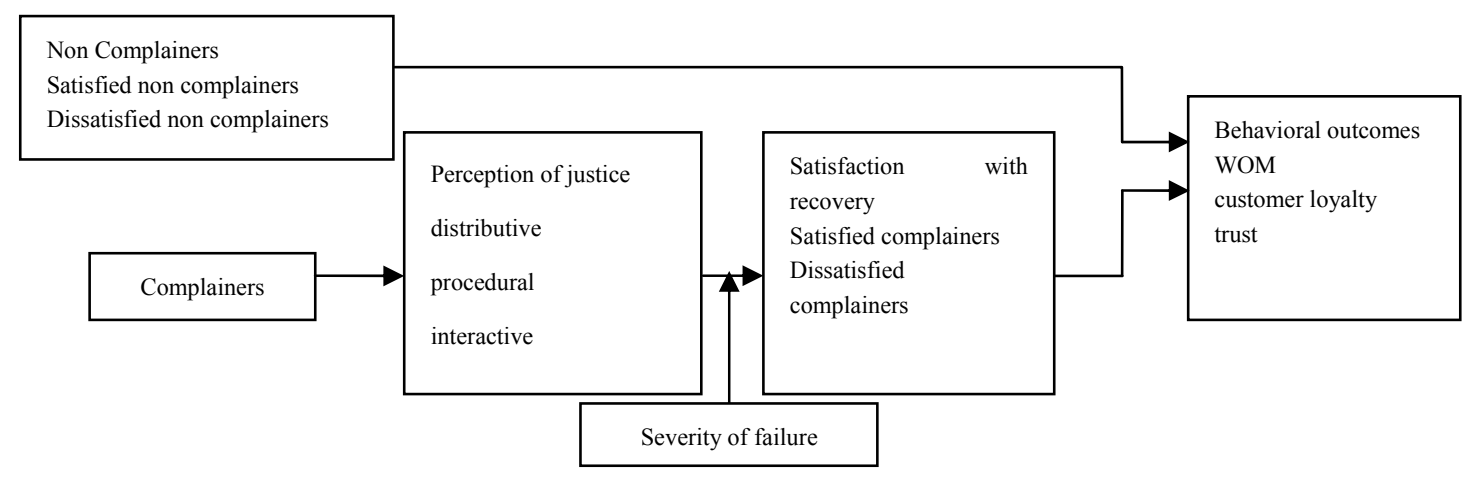

Figure 1. A theoretical framework for antecedent and outcomes of satisfaction with service recovery 


\section{Methodology}

\subsection{Research Design}

This study employed a cross-sectional survey design. Survey method is appropriate in collecting response on the majority of variables such as perception of justice, service failure severity, satisfaction with recovery and behavioral outcomes in real life experience. Survey method in examining service recovery had been conducted by Kau and Loh (2006). This method is convenient, fast and is a cost-effective means of eliciting responses from respondents (Zikmund, 1999). Customers at service providers' customer service centers in Berjaya Times Square (DIGI and U-Mobile), Jalan Ampang (CELCOM) and KLCC (MAXIS) in Klang Valley, Malaysia were participated in this study. The questionnaire was distributed personally using convenience sampling procedure to 450 respondents.

There were 2 sections in the questionnaires. Section A consists of the questionnaire about gender, education, age, ethnic group, monthly income, occupation, name of the service provider, plan chosen, how long is current plan and average monthly bill, awareness of MNP and their intention of leaving their current service provider. Section B consists of questionnaire regarding the satisfaction with service recovery construct was measured using 3 questions had been adapted from Cengiz et al. (2007). Initial Satisfaction level of respondent (complainers and non-complainers) was measured with 8 questions adopted from Kau and Loh, (2006). For perception of justice the 12 multi-items had been adapted from Cengiz et al. (2007). For behavioral outcomes (trust, word of mouth and consumer loyalty) consists of 12 questions were adopted from Kau and Loh (2006). Three questions to measured service failure severity adopted from Weun et al. (2004). The 5 Likert scale was used to measure the variables in this studied in order not to make the high number of questions boring, besides in order to increase answer percentage (Babakus, Yavas, Karatepe, \& Avci, 2003). Data was analyzed by using the Statistical Package for Social Science (SPSS) version 15.

\section{Results}

\subsection{Sample}

The sample consists of 280 respondents from service provider of telecommunication industry in Klang valley, Malaysia. Each questionnaire was distributed directly to the individual that was subscribed with mobile service provider and in a total of 450 questionnaires administered altogether. A total of 298 respondents were obtained However, only 280 questionnaires equally to 62.2 percent were considered for data analysis. The remaining 18 questionnaires were not taken into data collection due to questionnaires were not completed by the respondents.

Table 1. Respondent's profile

\begin{tabular}{lllll}
\hline Categories & Freq. & Percent & Complainers Percent & Non-complainers Percent \\
\hline Age & 1 & 0.4 & 100.0 & \\
$<20$ years old & 23 & 8.2 & 34.8 & 0.0 \\
Between 20-24 & 76 & 27.1 & 38.2 & 65.2 \\
Between 25-29 & 129 & 46.1 & 50.2 & 61.8 \\
Between 30-39 & 40 & 14.3 & 57.5 & 49.6 \\
Between 40-49 & 11 & 3.9 & 63.6 & 42.5 \\
$>=50$ years old & & & & 36.4 \\
Gender & 177 & 63.2 & 48.6 & \\
Male & 103 & 36.8 & 45.6 & 51.4 \\
Female & & & & 51.4 \\
Ethnicity & 153 & 54.6 & 39.9 & 60.1 \\
Malay & 69 & 24.6 & 52.2 & 47.8 \\
Chinese & 50 & 17.9 & 64.0 & 36.0 \\
Indian & 8 & 2.9 & 50.0 & 50.0 \\
Others & & & & \\
\hline
\end{tabular}




\begin{tabular}{lllll}
\hline Categories & Freq. & Percent & Complainers Percent & Non-complainers Percent \\
\hline Level of Education & & & & \\
Secondary School and Below & 30 & 10.7 & 43.3 & 56.7 \\
Certificate and Diploma & 108 & 38.6 & 41.7 & 58.3 \\
Degree or higer & 142 & 50.7 & 52.8 & 47.2 \\
Income Monthly & & & & \\
=< RM 1000 & 29 & 10.4 & 34.5 & 65.5 \\
RM 1001-RM 3000 & 115 & 41.1 & 38.3 & 61.7 \\
RM 3001-RM 5000 & 83 & 29.6 & 49.4 & 50.6 \\
$>$ RM 5000 & 53 & 18.9 & 71.7 & 28.3 \\
\hline
\end{tabular}

Table 1 illustrates the respondent's profile and distribution of complainers and non-complainers. Evidently, the sample represents higher number of males ( 177 or 63.2 percent) compared to females (103 or 36.8 percent). In terms of ethnicity, majority of respondents are predominantly Malay ( 54.6 percent), followed by Chinese (24.6 percent), Indian (17.9 percent) and others (2.9 percent). Pertaining to academic qualification, majority of respondents' qualification are degree or higher (50.7 percent), followed by certificate or Diploma (38.6 percent) and the least number of them having secondary or lower (10.7 percent). This finding implies that most of the respondents in Klang Valley who participated in the survey have a high level of education. From the results in Table 1 it indicated Indian and Chinese tended to have more complainers compared to Malays and the higher income group tended to have more complainers compared to lower income.

Table 2. Respondents' information for consumption choices

\begin{tabular}{|c|c|c|c|c|}
\hline Categories & Freq. & Percent & Complainers Percent & Non-complainers Percent \\
\hline \multicolumn{5}{|l|}{ Service Provider } \\
\hline MAXIS & 108 & 38.6 & 46.3 & 53.7 \\
\hline CELCOM & 111 & 39.6 & 51.4 & 48.6 \\
\hline DIGI & 48 & 17.1 & 47.9 & 52.1 \\
\hline U-MOBILE & 13 & 4.6 & 23.1 & 76.9 \\
\hline \multicolumn{5}{|l|}{ Plan } \\
\hline Postpaid & 147 & 52.5 & 59.9 & 40.1 \\
\hline Prepaid & 133 & 47.5 & 33.8 & 66.2 \\
\hline \multicolumn{5}{|l|}{ Duration of service } \\
\hline$<1$ year & 42 & 15.0 & 33.3 & 66.7 \\
\hline $1-3$ years & 56 & 20.0 & 46.4 & 53.6 \\
\hline $3-5$ years & 70 & 25.0 & 38.6 & 61.4 \\
\hline$>5$ years & 112 & 40.0 & 58.9 & 41.1 \\
\hline \multicolumn{5}{|c|}{ Average Bill Monthly } \\
\hline$<$ RM 50 & 43 & 15.4 & 23.3 & 76.7 \\
\hline RM 50-RM 100 & 96 & 34.3 & 47.9 & 52.1 \\
\hline RM 101-RM 150 & 59 & 21.1 & 54.2 & 45.8 \\
\hline RM 151-RM 200 & 53 & 18.9 & 54.7 & 45.3 \\
\hline > RM 200 & 29 & 10.4 & 55.2 & 44.8 \\
\hline \multicolumn{5}{|l|}{ MNP Awareness } \\
\hline YES & 253 & 90.4 & 51.4 & 48.6 \\
\hline
\end{tabular}




\begin{tabular}{lllll}
\hline Categories & Freq. & Percent & Complainers Percent & Non-complainers Percent \\
\hline NO & 27 & 9.6 & 11.1 & 88.9 \\
Intention to Switch & & & & \\
Yes & 112 & 40.0 & 50.0 & 50.0 \\
No & 168 & 60.0 & 45.8 & 54.2 \\
\hline
\end{tabular}

Table 2 depicts that majority of respondents who had participated in this survey are subscribing to CELCOM and MAXIS with a total that is close to 78.2 percent. On the other hand DIGI and U-MOBILE contributed to the balance of 21.7 percent of the respondents. Regarding average bill, the pattern is normal with average respondents spending between RM 50 to RM 150 which is about 55.4 percent. In term plan subscription is quite balance for respondents with postpaid having 52.5 percent and the balance being prepaid.

Duration pattern indicated that most of the respondents that been surveyed had been quite loyal to their current service provider. Survey results indicate 65 percent of the respondents had been with their service provider for more than 3 years. In terms of MNP awareness around Klang Valley it indicated that 90.4 percent are aware that it is available and 40 percent of the respondents surveyed indicated that they plan to change their service provider by still maintaining their number. In terms of complainer and non-complainers respondent pattern the result showed that complainers are more from postpaid compare to prepaid, the longer duration of service tend to have more complainers compare to shorter duration of service, higher average monthly bill tend to have more complainers compared to lower average monthly bill and MNP awareness is higher among the complainers compared to non-complainers

\subsection{Regression Analysis Result}

Regression was used to test hypotheses for $\mathrm{H} 1, \mathrm{H} 3 \mathrm{a}$ to $\mathrm{H} 3 \mathrm{c}$ and $\mathrm{H} 4 \mathrm{a}$ to H4c. This method was used to test direct relationship between independent and dependent variables. Hypotheses 1 is testing direct relationship between perception of justice and satisfaction with recovery. The regression tests for the relationship between perception of justice and satisfaction with recovery presented a strong inference with R square of .81 as shown in table 3 . Approximately 81.0 percent variations of satisfaction with service recovery can be explained by perception of justice. The Durbin-Watson value of 1.98 was confined to the acceptable range (1.5 to 2.5). The beta value (standardize coefficients) of perception of justice $(\beta=.90)$ were highly significant at $p<.01$ indicates that the independent variable are positively related to satisfaction with service recovery as shown in table 3 . Therefore hypothesis $\mathrm{H} 1$ is supported.

Table 3. Regression for satisfaction with service recovery (complainers)

\begin{tabular}{lll}
\hline Predictor Variable & Satisfaction with Service Recovery & \\
& Beta & t-value \\
\hline Perception of Justice & 0.90 & $23.75^{* *}$ \\
F value & 564.24 & \\
Durbin Watson & 1.98 & \\
R square & $0.81^{* *}$ & \\
Adjusted R square & $0.81^{* *}$ & \\
\hline
\end{tabular}

Note: $* * p<0.01$

In Table 4, hypotheses H3a, H3b and $\mathrm{H} 3 \mathrm{c}$ been tested. Approximately 73.0 percent variations of trust can be explained by satisfaction with service recovery. The Durbin-Watson value of 1.82 was confined to the acceptable range (1.5 to 2.5$)$. The beta value (standardize coefficients) of satisfaction with service recovery $(\beta=.85)$ were highly significant at $p<.01$ indicates that the independent variable are positively related to trust. Therefore hypothesis H3a is supported.

Approximately 71.0 percent variations of WOM can be explained by satisfaction with service recovery. The Durbin-Watson value of 1.82 was confined to the acceptable range (1.5 to 2.5). The beta value (standardize coefficients) of satisfaction with service recovery $(\beta=.85)$ were highly significant at $p<.01$ indicates that the independent variable are positively related to WOM. Therefore hypothesis H3b is supported. 
The regression tests result for the link between satisfaction with service recovery and customer loyalty had presented a strong inference with R square of .74 as depicted in table 4. Approximately 74.0 percent variations of customer loyalty can be explained by satisfaction with service recovery. The Durbin-Watson value of 1.71 was confined to the acceptable range (1.5 to 2.5$)$. The beta value (standardize coefficients) of satisfaction with service recovery $(\beta=.86)$ were highly significant at $p<.01$ indicates that the independent variable are positively related to customer loyalty as indicated in table 4 . Therefore hypothesis $\mathrm{H} 3 \mathrm{c}$ is supported.

Table 4. Regression for behavioral outcomes (complainers)

\begin{tabular}{|c|c|c|c|c|c|c|}
\hline \multirow{2}{*}{ Predictor Variable } & \multicolumn{2}{|l|}{ Trust } & \multicolumn{2}{|c|}{ Word of mouth } & \multicolumn{2}{|c|}{ Customer loyalty } \\
\hline & Beta & t-value & Beta & t-value & Beta & t-value \\
\hline Satisfaction with Service Recovery & 0.85 & $18.65^{* *}$ & 0.85 & $18.15^{* *}$ & 0.86 & $4.96^{* *}$ \\
\hline $\mathrm{F}$ value & 347.81 & & 329.32 & & 357.92 & \\
\hline Durbin Watson & 1.82 & & 2.09 & & 1.71 & \\
\hline $\mathrm{R}$ square & $0.73 * *$ & & $0.71 * *$ & & $0.67 * *$ & \\
\hline Adjusted R square & $0.72 * *$ & & $0.71 * *$ & & $0.73 * *$ & \\
\hline
\end{tabular}

Note: $* * p<0.01$

In Table 5, hypotheses $\mathrm{H} 4 \mathrm{a}, \mathrm{H} 4 \mathrm{~b}$ and $\mathrm{H} 4 \mathrm{c}$ been tested. All 3 hypotheses are testing direct relationship between non complainer and behavioral outcomes (trust, WOM and customer loyalty). The regression tests result for relationship between non complainer satisfaction and trust had presented a weak inference with R square of .30 . Approximately 30.0 percent variations of trust can be explained by non-complainer's satisfaction. The Durbin-Watson value of 1.74 was confined to the acceptable range (1.5 to 2.5$)$. The beta value (standardize coefficients) of non-complainers satisfaction $(\beta=.55)$ were highly significant at $p<.01$ indicate that the independent variable are positively related to trust. Therefore hypothesis H4a is supported.

The regression tests result for the relationship between non complainer satisfaction and WOM had presented a weak inference with R square of .38. Approximately 38.0 percent variations of WOM can be explained by non-complainer's satisfaction. The Durbin-Watson value of 1.94 was confined to the acceptable range (1.5 to $2.5)$. The beta value (standardize coefficients) of non-complainers satisfaction $(\beta=.61)$ highly significant at $p<.01$ indicates that the independent variable are positively related to WOM. Therefore hypothesis $\mathrm{H} 4 \mathrm{~b}$ is supported.

The regression tests result for the relationship between non complainer satisfaction and customer loyalty had presented a weak inference with R square of .29. Approximately 29.0 percent variations of customer loyalty can be explained by non-complainer's satisfaction. The Durbin-Watson value of 1.66 was confined to the acceptable range (1.5 to 2.5$)$. The beta value (standardize coefficients) of non-complainers satisfaction $(\beta=.54)$ highly significant at $p<.01$ indicates that the independent variable are positively related to customer loyalty. Therefore hypothesis $\mathrm{H} 4 \mathrm{c}$ is supported.

Table 5. Regression for behavioral outcomes (Non-complainers)

\begin{tabular}{|c|c|c|c|c|c|c|}
\hline \multirow{2}{*}{ Predictor Variable } & \multicolumn{2}{|l|}{ Trust } & \multicolumn{2}{|c|}{ Word of mouth } & \multicolumn{2}{|c|}{ Customer loyalty } \\
\hline & Beta & t-value & Beta & t-value & Beta & t-value \\
\hline Non-complainers Satisfaction & 0.55 & $7.84 * *$ & 0.61 & $9.36 * *$ & 0.54 & $7.60 * *$ \\
\hline $\mathrm{F}$ value & 61.40 & & 87.39 & & 57.80 & \\
\hline Durbin Watson & 1.74 & & 1.94 & & 1.66 & \\
\hline R square & $0.30 * *$ & & $0.38 * *$ & & $0.29 * *$ & \\
\hline Adjusted R square & $0.29 * *$ & & $0.37 * *$ & & $0.28 * *$ & \\
\hline
\end{tabular}

Note: $* * \mathrm{p}<0.01$

\subsection{Hierarchical Regression for Hypotheses Testing}

Hierarchical Regression was used to test hypotheses for H2. As depicted in Table 6 when the perception of justice is entered into the regression equation in step 1 , the coefficient determination $\left(R^{2}\right)$ was found to be 0.85 
indicating 84.5 percent of satisfaction with service recovery is explained by perception of justice In step 2 , service failure severity was entered into the equation in order to examine its impact as a moderator. The $\mathrm{R}^{2}$ increased from 84.5 percent to 85.8 percent indicating a change of 1.3 percent which is significant at $\mathrm{p}<0.01$. Finally, in the third step, the interaction terms (service failure severity * perception of justice) were entered accordingly into the model. The additional variance explained by the interaction terms (1.4 percent) was evidently significant at $\mathrm{p}<0.01$, implicating that there is a moderation effect of service failure severity on the relationships between perception of justice and satisfaction with service recovery. Therefore Hypothesis 2 was supported.

Table 6. Results of hierarchical regression analysis (satisfaction with service recovery)

\begin{tabular}{|c|c|c|c|}
\hline Variables & $\begin{array}{l}\text { Standard Beta } \\
\text { Step } 1\end{array}$ & $\begin{array}{l}\text { Standard Beta } \\
\text { Step } 2\end{array}$ & $\begin{array}{l}\text { Standard Beta } \\
\text { Step } 3\end{array}$ \\
\hline Independent Variables: Perception of Justice (PoJ) & $.92 * *$ & $.83 * *$ & $.53 * *$ \\
\hline Moderating Variable: Service Failure Severity (SFS) & & $-0.14 * *$ & $-0.56 * *$ \\
\hline Interaction Terms: SFS*PoJ & & & $0.35 * *$ \\
\hline $\mathrm{R}^{2}$ & .845 & .858 & .872 \\
\hline Adjusted $\mathrm{R}^{2}$ & .844 & .856 & .869 \\
\hline $\mathrm{R}^{2}$ Change & .845 & .013 & .014 \\
\hline F change & 694.966 & 11.097 & 13.520 \\
\hline Sig. F Change & 0.000 & 0.001 & 0.000 \\
\hline
\end{tabular}

Note: $* * \mathrm{p}<0.01$

\section{Discussions}

The result in this studied indicates organizational strategies used by the service providers for service recovery effort in turning dissatisfied complainers into satisfied customers have been evaluated overall by the respondents as perception of justice. If the respondents feel they have been treated justly, then their evaluation toward satisfaction with service recovery has also been rated as positive. This is in line with finding of Carr (2007). While Smith et al. (1999) findings in hotel and restaurant industry studied shows that procedural and interactional was found to be highly correlated and they recommended in their study that customers will react differently according to different industry. In Kau and Loh (2006) had utilize a different set of item (32 items) for perception of justice and found 4 factor instead of 3 factor in telecommunication industry in Singapore. In others studies Yang and Zhang (2012) have categorized distributive justice, procedural justice, and interactive justice as organizational justice and had found a positive effect on perceived organizational support towards professional managers in manufacturing and service industry in China.

The moderator impact of service failure severity was also found to be significant and impacting the relationship between perception of justice and satisfaction with service recovery. Service failure severity has also been recognized as an important variable by Weun et al. (2004). This indicates that as the service failure severity increases, satisfaction with service recovery is reduced even though perception of justice by customer towards service provider remains the same. This finding also indicates service providers need to be more careful when treating service failure. Severity of failure should be agreed mutually between service providers and the complainers. Service providers in Malaysia need to understand from this finding, what is defined by their customers as severity service failure and develop accordingly the necessary strategies to ensure effective service recovery in place in case failure does happen. This is in line with the research conducted by Weun et al. (2004) even though in their study, only one out of two element of perception of justice which was distributive justice had moderating effect.

Finding showed that complainers had positively linked trust, WOM and customer loyalty with satisfaction of service recovery. This indicated that if complainers are initially not satisfied but after service recovery effort was evaluated through satisfaction with recovery and then rated their outcome through behavioral outcomes such as trust, WOM and customer loyalty will show high correlation. The effective service recovery by service providers will help increase trust in customers and in turn will increase their loyalty towards the companies. Therefore the service providers need to implement various organizational strategies in ensuring that handling customer problems and failure always be first priority by the companies. On the other hand service provider need to be careful because with poor service recovery effort, mobile phone users will rate lower on their satisfaction with 
recovery and rate lower on behavioral outcomes too. This must be avoided especially with choice of alternative and low cost of switching currently in Malaysian market especially with MNP gaining momentum.

\section{Theoretical and Managerial Implications}

From theoretical implication the researchers in Malaysia can use this model for future research in service sector field such as banking, retailing and hotel to replicate and compare this finding. Currently there is limited research on non-complaints and this research indicates need to be understood further. The model needs to be enhanced further to understand why non complainants are not complaining. Furthermore the instruments used in this research are valid and reliable. Most of the results from this study show the similarities with studies done elsewhere except for the finding that perception of justice was identified as single construct instead of multi construct.

The current studied points to some useful guidelines for managerial action. Service providers need to understand that Malaysia is multi-racial and multi-cultural. From this results, ethnicity also exhibit different behavior towards perception of complaining. Therefore service providers need to have different strategies for different ethnicity (Mattila \& Patterson, 2004) to enhance effective service recovery and positive behavioral outcomes.

Service providers also need to formulate service recovery to reach non complainant by showing that service provider care for them. Service provider can reach them in many ways and try to understand their needs, wants and expectation. Service providers require providing staffs that have multi skill especially when launching new products/services. In case customer complain during this period of time, this specific staff if have been empowered can address this immediately or follow up again later to highlight that service provider value their current customers and create good reputation from customer's point of view. Furthermore with MNP, service provider need to be more proactive in understanding their customer better and one of it by intensifying customer loyalty program and organizing user forum in each state. This will help service providers to gain more market share with reduction in expenditure to attract new customers.

Customer loyalty can be nurtured by providing timely and reliable information. It can also be reinforced by the provision of honest information on what the service provider is doing about existing problems and what it does to forestall potential ones such as network quality (element of proactive service recovery effort). It is therefore important that effective conflict resolution mechanisms are not only in place but are proactive, so as to predict potential service failure and address them before problems become manifested. This is described as service recovery management.

\section{References}

Andreassen, T. W. (2000). Antecedents to satisfaction with service recovery. European Journal of Marketing, 34(1), 156-175. http://dx.doi.org/10.1108/03090560010306269

Babakus, E., Yavas, U., Karatepe, O., \& Avci, T. (2003). The effect of management commitment to service quality on employees affective and performance outcomes. Journal of the Academy of Marketing Science, 20(10), 1-15.

Berry, L. L., \& Parasuraman, A. (1991). Marketing services: Competing through quality. New York: The Free Press.

Bitner, M. J., Blooms, B. H., \& Tetreault, M. S. (1990). The service encounter: Diagnosing favorable and unfavorable incidents. Journal of Marketing, 54, 71-84. http://dx.doi.org/10.2307/1252174

Boshoff, C., \& Leong, J. (1998). Empowerment, attribution and apologizing as dimensions of service recovery. International Journal of Service Industry Management, 9(1), 24-47. http://dx.doi.org/10.1108/0956423 9810199932

Business Monitor International. (2009). Malaysian Telecom Report Q2 2009. London: Author.

Carr, C. L. (2007). The FAIRSERV model: Consumer reactions to services based on a multidimensional evaluation of service fairness. Decision Sciences, 38(1), 107-130. http://dx.doi.org/10.1111/j.1540-5915. 2007.00150.x

Casado-Díaz, A. B., Mas-Ruiz, F. J., \& Kasper, H. (2007). Explaining satisfaction in double deviation scenarios: The effects of anger and distributive justice. International Journal of Bank Marketing, 25(5), 292-314. http://dx.doi.org/10.1108/02652320710772970

Cengiz, E., Er, B., \& Kurtaran, A. (2007). The effects of failure recovery strategies on customer behaviours via complainants' perceptions of justice dimensions in banks. Banks and Banks Systems, 2(3), 173-196. 
Crie, D. (2003). Consumers' Complaint Behaviour: Taxonomy, typology and determinants: Towards a unified ontology. Database Marketing and Customer Strategy Management, 11(1). http://dx.doi.org/10.1057/ palgrave.dbm.3240206

Crosby, L. A., Evans, K. R., \& Cowles, D. (1990). Relationship quality in service selling: An interpersonal influence perspective. Journal of Marketing, 51, 11-27.

Frank, \& Sullivan. (2005). Asia Pacific Telecom CAPEX Spending. Retrieved March 16, 2009, from http://www. frost.com

Ganesan, S. (1994). Determinants of long-term orientation in buyer-seller relationships. Journal of Marketing, 58, 1-19. http://dx.doi.org/10.2307/1252265

Goodwin, C., \& Ross, I. (1992). Consumer responses to service failures: Influence of procedural and interactional fairness perception. Journal of Business Research, 25(2), 149-163. http://dx.doi.org/10.1016/ 0148-2963(92)90014-3

Hart, C. W. L., Heskett, J. L., \& Sasser, E. W. Jr. (1990). The profitable art of service recovery. Harvard Business Review, 68, 148-156.

Hoffman, D. K., Kelley, S. W., \& Bateson, J. E. G. (1997). Essentials of Services Marketing. New York: The Dryden Press.

Kelley, S. W., Hoffman, D. K., \& Davis, M. A. (1993). A typology of retail failures and Recovery. Journal of Retailing, 69(40), 429-452. http://dx.doi.org/10.1016/0022-4359(93)90016-C

Mack, R., Mueller, R., Crotts, J., \& Broderick, A. (2000). Perceptions, corrections and defections: Implications for service recovery in the restaurant industry. Managing Service Quality, 10(6), 339-346. http://dx.doi.org/10.1108/09604520010352256

Magnini, V. P., Ford, J. B., Markowski, E. P., \& Honeycutt Jr, E. D. (2007). The service recovery paradox: Justifiable theory or smoldering myth? Journal of Services Marketing, 21(3), 213. http://dx.doi.org/10.1108/ 08876040710746561

Mattila, A. S. (2001). The effectiveness of service recovery in a multi-industry setting. Journal of Services Marketing, 15(7), 583-596. http://dx.doi.org/10.1108/08876040110407509

Mattila, A. S., \& Patterson, P. G. (2004). Service Recovery and Fairness Perceptions in Collectivist and Individualist Contexts. Journal of Service Research, 6(4), 336. http://dx.doi.org/10.1177/1094670503262 947

Maxham, J. G. I. (2001). Service recovery's influence on consumer satisfaction, positive word-of-mouth and purchase intentions. Journal of Business Research, 54, 11-24. http://dx.doi.org/10.1016/S0148-2963(00) 00114-4

Maxham, J. G. I., \& Netemeyer, R. G. (2003). Firms reap what they sow: The effects of shared values and perceived organizational justice on customers' evaluation of complaint handling. Journal of Marketing, 67(1), 29-45. http://dx.doi.org/10.1509/jmkg.67.1.46.18591

McCollough, M. A., Berry, L. L., \& Yadav, M. S. (2000). An empirical investigation of customer satisfaction after service failure and recovery. Journal of Service Research, 3, 121-137. http://dx.doi.org/10.1177/109 467050032002

Michel, S. (2001). Analyzing service failures and recoveries: A process approach. International Journal of Service Industry Management, 12(1), 20-33. http://dx.doi.org/10.1108/09564230110382754

Morgan, R. M., \& Hunt, S. D. (1994). The commitment trust theory of marketing Relationships. Journal of Marketing, 58, 20-38. http://dx.doi.org/10.2307/1252308

Ndubisi, N. O. (2004). Understanding the salience of cultural dimensions on relationship marketing, its underpinnings and aftermaths. Cross Cultural Management, 11(3), 70-89. http://dx.doi.org/10.1108/135276 00410797855

Ndubisi, N. O. (2005). Effect of gender on customer loyalty: A relationship marketing approach. Marketing Intelligence \& Planning, 24(1), 48-61. http://dx.doi.org/10.1108/02634500610641552

Ndubisi, N. O., \& Ling, T. Y. (2006). Complaint behaviour of Malaysian consumers. Management Research News, 29(1/2), 65-76. http://dx.doi.org/10.1108/01409170610645457

Oliver, R. L. (1980). A Cognitive Model of the Antecedents and Consequences of Satisfaction Decisions. Journal 
of Marketing Research, 17, 460-469. http://dx.doi.org/10.2307/3150499

Reichheld, F. F., \& Sasser, E. W. (1990). Zero defects: Quality comes to services. Harvard Business Review, 68, 105-111.

Seth, A., Momaya, K., \& Gupta, H. M. (2005). An exploratory investigation of customer loyalty and retention in cellular mobile communication. Journal of Services Research: Special Issue, 173-185.

Shapiro, T., \& Nieman-Gonder, J. (2006). Effect of communication mode in justice-based service recovery. Managing Service Quality, 16(2), 124. http://dx.doi.org/10.1108/09604520610650619

Soo, E. J. (2009, February 23). The perils of modern day mobile technology. The Star, B2.

Sparks, B. A., \& McColl-Kennedy, J. R. (2001). Justice strategy options for increased customer satisfaction in a services recovery setting. Journal of Business Research, 54(12), 209-218. http://dx.doi.org/10.1016/S01482963(00)00120-X

Stauss, B., \& Schoeler, A. (2004). Complaint management profitability: What do complaint managers know? Managing Service Quality, 14(2/3), 147-156. http://dx.doi.org/10.1108/09604520410528572

Swanson, S. R., \& Kelley, S. W. (2001). Service recovery attributions and word-of-mouth intentions. European Journal of Marketing, 35(1), 194-211. http://dx.doi.org/10.1108/03090560110363463

Tax, S. S., \& Brown, S. W. (2000). Service recovery: Research insights and practices. In T. A. Swartz, \& D. Iacobucci (Eds.), Handbook of services marketing and management (pp. 271-285). Thousand Oaks, CA: Sage Publication. http://dx.doi.org/10.4135/9781452231327.n19

Tax, S. S., Brown, S. W., \& Chandrashekaran, M. (1998). Customer evaluation of service complaint experiences: Implications for relationship marketing. Journal of Marketing, 62, 60-76. http://dx.doi.org/10.2307/ 1252161

Weun, S., Beatty, S. E., \& Jones, M. A. (2004). The impact of service failure severity on service recovery evaluations and post-recovery. Journal of Services Marketing, 18(2), 133-146. http://dx.doi.org/10.1108/ 08876040410528737

Yang, F., \& Zhang, L. (2012). Organizational justice and perceived organizational support: The moderating role of conscientiousness in China. Nankai Business Review International, 3(2), 145-166. http:/dx.doi.org/ $10.1108 / 20408741211244398$

Yi, W. F., Cheng, C. W., \& Wei, T. W. (2010). The impacts of online retailing service recovery and perceived justice on consumer loyalty. International Journal of Electronic Business Management, 8(3), 239-249.

Yuen, M. K. (2008, November 11). MNP snag to be resolved by year-end, says minister. The Star, N10.

Zeithaml, V. A., Berry, L. L., \& Parasuraman, A. (1993). The Nature and Determinants of Customer Expectations of Service. Journal of the Academy of Marketing Science, 21, 1-12. http://dx.doi.org/10.1177/0092070393 211001

Zeithaml, V. A., Parasuraman, A., \& Berry, L. (1985). A conceptual model of service quality and its implication for future research. Journal of Marketing, 49, 41-50. http://dx.doi.org/10.2307/1251430

\section{Copyrights}

Copyright for this article is retained by the author(s), with first publication rights granted to the journal.

This is an open-access article distributed under the terms and conditions of the Creative Commons Attribution license (http://creativecommons.org/licenses/by/3.0/). 